A N N A L E S

UNIVERSITATIS MARIAE CURIE-SKŁODOWSKA LUBLIN - POLONIA

VOL. LXV, z. 2

SECTIO F

2010

\title{
RENATA ŚLUSARSKA
}

Lublin

\section{Udział Królestwa Polskiego w finansach Rosji na przełomie XIX i XX stulecia}

Teilnahme vom Königreich Polen an den Finanzen

Russlands um die Wende des XIX. zum XX. Jahrhundert

Po stłumieniu powstania styczniowego władze centralne w Królestwie Polskim zostały ostatecznie zlikwidowane i zaprowadzono rosyjską administrację. W wyniku tego przekształcenia administracyjnego w latach 1867-1870 skasowano skarbowość polską i Królestwo Polskie pod względem skarbowym stało się integralną częścią Rosji.

Kwestia udziału dochodów z Królestwa w budżecie państwa rosyjskiego wzbudzała liczne dyskusje, zwłaszcza w początkach XX stulecia. Wielu czołowych ekonomistów polskich podjęło się zadania ustalenia rzeczywistego udziału Królestwa $\mathrm{w}$ finansach Rosji ${ }^{1}$. Niezależnie od tego, $\mathrm{z}$ jakiej pozycji rozpatrywali oni dostępne dane kontroli państwowej, wniosek był wspólny - Królestwo Polskie było krajem bardzo dochodowym dla skarbu państwa. Jednocześnie było obszarem, gdzie obciążenie podatkowe, zwłaszcza jeśli chodzi o podatki bezpośrednie, było znacznie wyższe w porównaniu z innymi prowincjami państwa. Jeśli zaś chodzi o wydatki ponoszone przez skarb na rzecz guberni polskich, to nie przewyższały one kosztów w innych okręgach Rosji. W pewnych dziedzinach wydatki na potrzeby miejscowe były natomiast znacznie mniejsze niż w innych rejonach państwa.

${ }^{1}$ W. Grabski, Balans Carstva Polskogo w finansach Rossijskoj Imperii, Warszawa 1909, s. 35; zob też: R. Kołodziejczyk, Jan Bloch (1836-1902). Szkic do portretu „króla polskich kolei”, Warszawa 1983, s. 187-206. 
Budżet państwa rosyjskiego oparty był na podatkach pośrednich i dochodach prywatno-gospodarczych. W przypadku tych drugich wpływy z kolei żelaznych miały największe znaczenie ( $814 \mathrm{mln}$ rubli w $1913 \mathrm{roku})$, w podatkach pośrednich - monopol wódczany (899,3 mln rubli), który przynosił państwu przeszło $1 / 4$, mianowicie $26 \%$, ogólnych dochodów ${ }^{2}$. Rozwój opodatkowania bezpośredniego był natomiast słaby w całym państwie rosyjskim, także w Królestwie Polskim. Również w guberniach polskich największą rolę odgrywały podatki pośrednie, następnie dochód z własności i przedsiębiorstw państwowych. Niemniej jednak stwierdzić należy, iż mimo że system podatków bezpośrednich skonstruowany był dość prymitywnie, stałym zjawiskiem, zwłaszcza w początkach XX wieku, był wzrost dochodów z tej kategorii podatków, co dotyczyło zarówno Rosji, jak i Królestwa Polskiego. Udział Królestwa w dochodach budżetowych Rosji w początkach XX wieku ilustruje tabela.

Tabela 1. Udział Królestwa Polskiego w finansach Rosji w latach 1905-1911 (w mln rubli)

\begin{tabular}{|l|c|c|c|c|c|c|c|c|}
\hline & \multicolumn{2}{|c|}{1905} & \multicolumn{2}{|c|}{1907} & \multicolumn{2}{|c|}{1909} & \multicolumn{2}{|c|}{1911} \\
\cline { 2 - 9 } & Królestwo & Cesarstwo & Królestwo & Cesarstwo & Królestwo & Cesarstwo & Królestwo & Cesarstwo \\
\hline $\begin{array}{l}\text { Podatki } \\
\text { bezpo- } \\
\text { średnie }\end{array}$ & 18112 & 126896 & 23528 & 183322 & 27272 & 198689 & 28958 & 224070 \\
\hline $\begin{array}{l}\text { Podatki } \\
\text { pośrednie }\end{array}$ & 58630 & 508586 & 87237 & 632433 & 101207 & 681565 & 130768 & 820166 \\
\hline $\begin{array}{l}\text { Dochody } \\
\text { z własno- } \\
\text { ści }\end{array}$ & 42833 & 1239491 & 53257 & 1427570 & 56296 & 1523732 & 64316 & 1779748 \\
\hline Ogółem & 119575 & 1874973 & 164022 & 2243325 & 184777 & 2403986 & 224042 & 2823984 \\
\hline
\end{tabular}

Źródło: Rocznik statystyczny Królestwa Polskiego. Rok 1913, Warszawa 1914, s. 218.

Dochody zwyczajne skarbu państwa, wynoszące 2823984000 rubli w 1911 roku, rosły stale od 1905 roku (wówczas wynosiły 1874973000 rubli). Dochody nadzwyczajne wahały się z roku na rok znacznie. Miały źródło prawie wyłącznie w pożyczkach. Spadały w latach spokojnych oraz urodzajnych, rosły w latach wojny i rewolucji, np. w 1906 roku osiągnęły sumę 1084110000 rubli, w 1911 - 2567000 rubli. Również w Królestwie Polskim dochody zwyczajne wzrastały stale i regularnie, od 119575000 rubli w roku 1905 do 224042000 rubli w roku 1911. Przyrost w ciągu siedmiu lat wyniósł $87 \%$, podczas gdy przyrost dochodów zwyczajnych w całym państwie wyniósł ponad $50 \%{ }^{3}$.

${ }^{2}$ E. Strasburger, Udział Królestwa Polskiego w finansach Rosji, Warszawa 1918, s. 8.

${ }^{3}$ Rocznik statystyczny Królestwa Polskiego. Rok 1913, Warszawa 1914, s. 217-218. Stały wzrost 
Królestwo Polskie było dla budżetu państwa rosyjskiego prowincją niewątpliwie dochodową. $Z$ własnych zasobów finansowych dostarczało skarbowi dodatkowych środków na pokrycie nadzwyczajnych wydatków całego państwa, które w bardzo niewielkim stopniu przynosiły korzyść Królestwu (skarb budował tutaj bardzo mało kolei i nie ponosił specjalnych wydatków). Królestwo było bardzo produktywnym obszarem odnośnie do podatków bezpośrednich. Nieco inaczej wyglądała sprawa $\mathrm{w}$ dziedzinie podatków pośrednich w związku z mniejszym spożyciem wódki niż w innych częściach imperium. Niemniej jednak o ile w guberniach rosyjskich wyższe były dochody z produkcji wódki, o tyle mniejsze było zużycie takich towarów obłożonych akcyzą, jak: cukier, zapałki, tytoń, nafta. Większe było w Królestwie zużycie tych towarów, również importowanych, w związku z jego przygranicznym położeniem, gęstym zaludnieniem, a także stosunkowo dużym procentem ludności miejskiej w porównaniu z rolniczymi guberniami rosyjskimi położonymi w głębi kraju

Dodatni bilans Królestwa w dochodach państwowych utrzymywał się także w latach następnych. Nadal największe wpływy przynosiły podatki pośrednie, następnie dochody z majątku państwowego. Większą stosunkowo rolę niż w Rosji odgrywało obciążenie ziemi i nieruchomości miejskich, bo wynosiło $52 \%$ wpływów z podatków bezpośrednich, podczas gdy podatek przemysłowy przynosił 42\% dochodów z tej kategorii podatków5. Poniższa tabela daje obraz udziału Królestwa w dochodach Rosji w 1913 roku.

Tabela 2. Udział Królestwa Polskiego w dochodach skarbowych Rosji w 1913 roku

\begin{tabular}{|l|c|r|c|c|c|}
\hline & \multicolumn{2}{|c|}{ Rosja } & \multicolumn{3}{c|}{ Królestwo Polskie } \\
\cline { 2 - 6 } & W mln rb. & $\%$ & W mln rb. & $\%$ & $\begin{array}{c}\text { Stosunek \% do } \\
\text { dochodów w Rosji }\end{array}$ \\
\hline $\begin{array}{l}\text { Majątek, przedsiębiorstwa } \\
\text { państwowe }\end{array}$ & 1169,1 & 34,2 & 101,2 & 34,3 & 8,9 \\
\hline Podatki bezpośrednie & 272,5 & 8,2 & 32,8 & 11,2 & 12,0 \\
\hline Podatki pośrednie & 1608,3 & 46,6 & 137,6 & 46,6 & 8,5 \\
\hline
\end{tabular}

dochodów państwowych w Królestwie Polskim występował właściwie od lat siedemdziesiątych XIX wieku. W ciągu 25-lecia (1876-1901) podatki bezpośrednie wzrosły o $12 \mathrm{mln}$ rb., tj. o 140\%, pośrednie o $39 \mathrm{mln}$ rb., tj. niemal o 125\%, S. Dziewulski, Dochody i wydatki skarbu na przestrzeni Królestwa Polskiego, „Ekonomista” 1904, t. 1, s. 120.

${ }^{4}$ W. Grabski, op. cit., s. 14 .

${ }^{5}$ E. Taylor, Prawo skarbowe Rzeczypospolitej Polskiej, cz. I, Poznań 1920, s. 18. W Rosji największe dochody przynosił podatek przemysłowy - 55\% wpływów z podatków bezpośrednich, ibidem. 
cd. Tabela 2. Udział Królestwa Polskiego w dochodach skarbowych Rosji w 1913 roku

\begin{tabular}{|l|c|c|c|c|c|}
\hline \multirow{2}{*}{} & \multicolumn{2}{|c|}{ Rosja } & \multicolumn{3}{c|}{ Królestwo Polskie } \\
\cline { 2 - 6 } & W mln rb. & $\%$ & W mln rb. & $\%$ & $\begin{array}{c}\text { Stosunek \% do do- } \\
\text { chodów w Rosji }\end{array}$ \\
\hline Podatki od obrotu i opłaty & 231,1 & 6,7 & 18,7 & 6,3 & 8,1 \\
\hline Inne dochody & 136,4 & 3,9 & 5,2 & 1,6 & 3,8 \\
\hline Dochody nadzwyczajne & 13,8 & 0,4 & - & - & - \\
\hline Ogółem & 3431,2 & 100,0 & 295,5 & 100,0 & 8,5 \\
\hline
\end{tabular}

Źródło: E. Strasburger, Udział Królestwa Polskiego w finansach Rosji, Warszawa 1918, s. 12.

Dochody z Kongresówki w 1913 roku wynosiły 295500000 rubli. Składały się na nie dochody z podatków pośrednich, przynoszące największe wpływy - 46,6\%, dochody z majątku i przedsiębiorstw były na drugim miejscu (34,3\%). Podatki bezpośrednie przynosiły $11,2 \%$ wpływów, podatki od obrotu i opłaty 1,6\%. Podatki bezpośrednie dawały w Królestwie większe dochody niż w Rosji, gdzie stanowiły $8,2 \%$ wpływów budżetowych.

Wspomniano wcześniej, że wśród podatków pośrednich dochód niższy, w porównaniu z Rosją, przynosił monopol wódczany, zaledwie 5,6\% odnośnych dochodów w Cesarstwie. Ludność polska konsumowała mniej wódki niż przeciętnie Rosja europejska; na głowę przypadało spożycie wódki w litrach: w 1905 roku w Królestwie - 4,55, w Rosji - 6,88; w 1913 roku w Królestwie - 5,41, w Rosji - 8,48. Wśród guberni Królestwa najwięcej spożywano wódki w guberniach najbardziej uprzemysłowionych - warszawskiej i piotrkowskiej ${ }^{6}$.

Dochody skarbowe Rosji w Królestwie Polskim były na ogół wyższe od współczynnika ludności. Dawało to około 8,5\% dochodów całego państwa, podczas gdy ludność jego stanowiła tylko $7,5 \%{ }^{7}$.

Po tym schematycznym przedstawieniu rosyjskich źródeł budżetowych należy przejść do rozpatrzenia ustroju skarbowego, obowiązującego w Rosji oraz Królestwie Polskim, oraz głównych rodzajów dochodów państwa rosyjskiego, których całość była odzwierciedleniem stosunków gospodarczych, społecznych i politycznych kraju.

Do dochodów skarbowych państwa zaliczone zostały dochody od majątku i przedsiębiorstw państwowych, takich jak: lasy, koleje, poczta i telegraf. W Rosji bardzo poważną pozycję budżetową stanowiły dochody z lasów. Również w Królestwie majątki rządowe w większości były zalesione. Lasy rządowe stanowiły w 1912 roku 40\% zalesionej powierzchni całego kraju. Dochody

${ }^{6}$ E. Strasburger, op. cit., s. 28.

${ }^{7}$ E. Taylor, Polityka skarbowa i system podatkowy Rzeczypospolitej Polskiej, Poznań 1929, s. 4. 
z jednego hektara lasów rządowych w Królestwie były wyższe niż w Rosji, co tłumaczyło się wyższą ceną drzewa ${ }^{8}$. Sposób eksploatacji lasów był w Królestwie na ogół bardzo elementarny. Przeszło 9/10 dochodów wpływało jako opłata za drzewo na pniu. Dochód leśny w Królestwie dawał rocznie około $5 \mathrm{mln}$ rubli, co stanowiło przeszło 9\% ogólnych wpływów z tej pozycji ${ }^{9}$.

Koleje w Rosji miały pod względem finansowym doniosłe znaczenie. Zyski te ograniczone były niestety koniecznością spłaty olbrzymiego długu zaciągniętego na budowę dróg żelaznych ${ }^{10}$. W Królestwie dochody z kolei, głównie z uwagi na niewielką długość sieci kolejowej, nie przynosiły wielkich zysków. W 1914 roku zyski stanowiły 1/10 ogólnych dochodów kolejowych w całej Rosji ${ }^{11}$.

Poczta w Rosji była słabo rozwinięta, co związane było z małą ilością dróg żelaznych w stosunku do obszaru państwa. Niski stopień oświaty sprawiał również, że ludność rzadko korzystała z jej usług. Pod względem skarbowym poczta i telegraf przynosiły znaczne zyski, głównie wskutek wysokich opłat. Dochód z tego źródła wynosił w Rosji w 1913 roku 120 mln rubli. Udział Królestwa w dochodach z poczty i telegrafu wyrażał się w sumie $10 \mathrm{mln}$ rubli, czyli stanowił $8 \%$ ogólnych dochodów ${ }^{12}$.

Natomiast zupełnie nieznaczące były w Królestwie dochody z dzierżaw gruntów należących do państwa - 0,9\% ogólnych dochodów ${ }^{13}$.

Reasumując wszystkie pozycje, przeciętny udział Królestwa Polskiego we wpływach z dóbr i przedsiębiorstw państwowych można określić na 101,2 mln rubli, co stanowiło 8,9\% dochodów z tego tytułu w całym państwie ${ }^{14}$.

${ }^{8}$ Dochód z jednego hektara lasu w Rosji wynosił 80 kop.; w Królestwie - 9 rb., E. Strasburger, op. cit., s. 14.

${ }^{9}$ W. Żukowski, Dochody i wydatki państwowe w Królestwie Polskim, Warszawa 1907, s. 67.

${ }^{10} \mathrm{~W} 1913$ roku dochód z kolei wyniósł 813,3 mln rb. Po odliczeniu wydatków na eksploatację oraz spłatę zaciągniętych pożyczek zysk wynosił tylko 33,3 mln rb., do tego dochodził udział w zyskach z eksploatacji kolei prywatnych, łącznie - 59,9 mln rb., E. Strasburger, op. cit., s. 14.

${ }^{11} \mathrm{~W}$ latach poprzednich udział Królestwa w dochodach kolejowych stanowił 5-6\% ogólnych wpływów państwowych, W. Żukowski, op. cit., s. 65.

${ }^{12}$ E. Strasburger, op. cit., s. 16. Głównym źródłem dochodów była sprzedaż znaczków pocztowych. Liczba instytucji pocztowych była w Królestwie stosunkowo niewielka - 380 na ogólną liczbę 4890. Względy natury gospodarczej i cywilizacyjnej zadecydowały o tym, że w Królestwie częściej korzystano z usług tych instytucji, W. Żukowski, op. cit., s. 55.

${ }^{13}$ E. Strasburger, op. cit., s. 11. Znacznie wyższe były dochody z tego tytułu w Rosji - w roku 1913 ponad $40 \mathrm{mln}$ rb. Dochodowa była dla skarbu zwłaszcza dzierżawa gruntów nafto- i złotodajnych, ibid., s. 11.

${ }^{14}$ Ibidem. W latach 1901-1905 dochody z majątku i przedsiębiorstw państwowych stanowiły około $6 \%$ ogólnych wpływów, W. Żukowski, op. cit., s. 79. 
Drugą kategorię dochodów zwyczajnych państwa stanowiły dochody pobierane $\mathrm{w}$ formie podatków i opłat. Przy rozpatrywaniu podatków zastosowano utarty podział na pośrednie (w tym monopol wódczany i cła) oraz bezpośrednie.

Podatki pośrednie przynosiły bardzo znaczne dochody, w roku 1913 - ponad 46\% wpływów budżetowych. Wpływy z tego źródła, wraz z dochodami z majątków rządowych, dawały razem $4 / 5$ wszystkich dochodów.

Poważne znaczenie finansowe miały dla budżetu cła, mimo że służyły głównie celom gospodarczym i ochronie przemysłu. Dochód z ceł zajmował w budżecie rosyjskim pod względem fiskalnym trzecie miejsce - po monopolu wódczanym i kolejach. W 1913 roku dochody celne przyniosły skarbowi państwa 352,9 mln rubli. Wśród ceł największe dochody dawało cło od herbaty - 1/4 dochodu z wszystkich ceł. Podobną rolę odgrywało cło od bawełny. Udział Królestwa Polskiego w cłach stanowił około 13\% ogólnych dochodów. Wysoki udział Królestwa był wynikiem jego przygranicznego położenia oraz większego spożycia towarów importowanych ${ }^{15}$.

Ogromne wpływy budżetowe przynosił monopol wódczany - 899,3 $\mathrm{mln}$ rb. w 1913 roku. Produkcja wódki pozostawiona była osobom prywatnym, sprzedaż została natomiast zmonopolizowana i stanowiła wyłączny przywilej rządu. Cenę wódki monopolowej regulował corocznie minister finansów. Z guberni polskich wpływało do budżetu $z$ tego tytułu $50,5 \mathrm{mln}$ rubli, tj. 5,6\%. Wyżej wspomniano, że wynikało to przede wszystkim z mniejszego spożycia wódki w Królestwie w porównaniu z innymi guberniami rosyjskimi ${ }^{16}$.

Natomiast na obszarze Królestwa większe było spożycie innych towarów obłożonych akcyzą, zwłaszcza takich jak cukier (14,0\% odnośnych dochodów Rosji), tytoń (12,6\%), trunki (8,7\%). Z przedmiotów obłożonych podatkiem konsumpcyjnym wymienić jeszcze należy naftę i zapałki. Udział Królestwa wynosił tutaj odpowiednio - 8,3\% i 6,5\%. Wyższe niż w Rosji spożycie tych towarów związane było głównie z szybszą urbanizacją Królestwa. Konsumentami towarów opodatkowanych akcyzą była głównie ludność miejska. Ogólny udział Królestwa w dochodach z podatków pośrednich wynosił $8,5 \%{ }^{17}$.

Znacznie mniejsze wpływy budżetowe pochodziły z podatków bezpośrednich. Najważniejszą kategorię wśród nich stanowiły podatki gruntowe i od nieruchomości oraz podatek przemysłowy. Znaczenie budżetowe tej kategorii po-

\footnotetext{
${ }^{15}$ W. Grabski, op. cit., s. 22.

${ }^{16}$ E. Strasburger, op. cit, s. 28.

${ }^{17}$ W. Grabski, op. cit., s. 14; E. Strasburger, op. cit., s. 11.
} 
datków było niegdyś znacznie poważniejsze. W latach siedemdziesiątych XIX wieku wpływy te stanowiły około $28 \%$ ogółu dochodów. W następnych latach nastąpił upadek doniosłości budżetowej podatków bezpośrednich, pomimo ich absolutnego wzrostu. Z 10\% w 1891 roku stosunek procentowy do ogółu dochodów spadł w 1900 roku do 7,5\%, w 1905 do 6,0\%. W Królestwie Polskim podatki bezpośrednie kształtowały się inaczej i stanowiły na początku wieku 14-15\% ogólnych dochodów z Królestwa. W 1913 roku wpływy z tego tytułu przynosiły ponad 12\% ogólnych wpływów z Królestwa ${ }^{18}$. Udział Królestwa w dochodach z podatków bezpośrednich ilustruje tabela.

Tabela 3. Udział Królestwa Polskiego w dochodach z podatków bezpośrednich w latach 1901-1905 (w mln rubli)

\begin{tabular}{|l|r|r|r|r|r|r|r|r|r|}
\hline \multirow{2}{*}{ Podatek } & \multicolumn{4}{|c|}{1901} & \multicolumn{3}{c|}{1903} & \multicolumn{3}{c|}{1905} \\
\cline { 2 - 11 } & Królestwo & Cesarstwo & $\%$ & Królestwo & Cesarstwo & $\%$ & Królestwo & Cesarstwo & $\%$ \\
\hline $\begin{array}{l}\text { Gruntowy } \\
\text { i od nierucho- } \\
\text { mości }\end{array}$ & 11668 & 44704 & 26,1 & 12878 & 49884 & 25,6 & 11664 & 45316 & 25,7 \\
\hline Przemysłowy & 6960 & 68824 & 10,1 & 7290 & 67590 & 10,7 & 5957 & 62048 & 9,6 \\
\hline Od kapitałów & 794 & 17362 & 4,5 & 937 & 17756 & 5,2 & 1105 & 19532 & 5,6 \\
\hline Ogółem & 19422 & 130890 & 14,8 & 21105 & 135230 & 15,5 & 18726 & 126896 & 14,7 \\
\hline
\end{tabular}

Źródło: W. Żukowski, Dochody i wydatki państwowe w Królestwie Polskim, Warszawa 1907, s. 18; E. Strasburger, op. cit., s. 11.

Przytoczone dane świadczą o tym, że w Królestwie Polskim największe wpływy wśród podatków bezpośrednich dawał podatek gruntowy i od nieruchomości: 25-26\% ogólnych dochodów z tego tytułu. Podatek przemysłowy z Królestwa stanowił 9-10\% ogólnych dochodów skarbowych z tego podatku. W 1913 roku dochody z podatków gruntowego i od nieruchomości stanowiły 19,7\% wpływów państwowych z tego tytułu. Dochody z podatków przemysłowego i od kapitałów utrzymały się mniej więcej na tym samym poziomie i wynosiły odpowiednio - 9,2\% i 5,3\% odnośnych dochodów Rosji ${ }^{19}$.

Wydajność podatku gruntowego w Rosji była stosunkowo niska, jeśli weźmie się pod uwagę znaczenie, jakie posiadało w tym kraju rolnictwo. Taryfa podatkowa chwiała się z dziesięciny gruntu od 1/4 kopiejki w guberni archangielskiej do 17 kopiejek w guberni kurskiej. Od hektara ziemi ornej płacono przeciętnie 10 kopiejek, natomiast hektar ziemi w Królestwie opłacał 90 kopiejek podatku gruntowego wraz z podymnym. Państwo rosyjskie zatem osiągało z podatku

${ }^{18}$ W. Żukowski, op. cit., s. 16.

${ }^{19}$ E. Strasburger, op. cit, s. 11. 
gruntowego w Królestwie względnie wysoki dochód, mianowicie 9 mln rubli, podczas gdy podatek ten przyniósł w Rosji w 1913 roku - 18615070 rubli $^{20}$.

Stosunkowo wysokie, w porównaniu z resztą państwa, było obciążenie nieruchomości miejskich. Wpływy z tego tytułu z Królestwa stanowiły 25\% ogółu wpływów w państwie. Obciążenie nieruchomości miejskich w Królestwie stanowiło 10\% domniemanego dochodu, przy czym do oszacowania nieruchomości fabrycznych wliczano wartość maszyn. Obciążenie nieruchomości w Rosji nie przewyższało 3,5\% dochodu, nie wliczano tam również dochodu z maszyn, przy szacowaniu dochodów $\mathrm{z}$ nieruchomości fabrycznych ${ }^{21}$.

Znaczne zyski przynosił skarbowi podatek przemysłowy opłacany przez przemysł i handel. Większą część tego podatku stanowiły opłaty od patentów oraz świadectw przemysłowych, mniejszą podatek od czystego zysku przedsiębiorstw. Z powodu skomplikowanej budowy tego podatku wpływy z tego tytułu tylko $\mathrm{w}$ pewnym stopniu były zależne od rzeczywistych rezultatów przemysłu i handlu. Niemniej jednak zmiany w dochodach $\mathrm{z}$ tego podatku mogą być ilustracją obrotów przemysłu i handlu. Wydajność podatku przemysłowego wzrastała w Rosji nieustannie od lat dziewięćdziesiątych XIX wieku. W roku 1900 podatek ten przyniósł 69,8 mln rubli, w 1908 roku - 104,8 mln rubli, w 1913 - 150,1 mln rubli. Wzrost dochodów z niego dotyczył także Królestwa: $\mathrm{w} 1901$ roku wpływy z tego podatku osiągnęły sumę 6,9 mln rubli, w 1913 - 13,8 mln rubli. Jedynie w pierwszych latach XX wieku nastąpiły pewne wahania dochodów z podatku przemysłowego. W Rosji na dochody z tego źródła wpływ miał nieurodzaj lat 1901-1902, w 1904 roku wojna z Japonią, w 1905 roku rewolucja. W Królestwie, przeciwnie, dostrzegalny był stały wzrost, aż do roku 1904 włącznie. Dopiero rok 1905 przyniósł spadek wpływów o przeszło $1,5 \mathrm{mln} \mathrm{rb}$., tj. o 25\%. Najdotkliwiej przesilenie uwydatniło się w przemyśle włókienniczym, żelaznym i mechanicznym, jako rezultat strajków i zakłócenia organizacji pracy, oraz w przemyśle budowlanym dotkniętym zastojem w budownictwie ${ }^{22}$.

Trzecia kategoria dochodów zwyczajnych, dotycząca opłat i podatków od obrotu, obejmowała przede wszystkim opłaty stemplowe, podatki od obrotów majątkowych oraz podatek od spadków i darowizn. W 1913 roku dochody te

${ }^{20}$ Ibid., s. 17.

${ }^{21}$ W. Żukowski, op. cit., s. 19.

${ }^{22}$ Ibid., s. 23. W 1885 roku wprowadzono podatek od kapitałów. Dotyczył on dochodów od papierów procentowych państwowych, publicznych i prywatnych. Stopa wynosiła 5\%. Dochód z tego podatku za 1913 roku w Rosji wyniósł 35,1 mln rb., w Królestwie - 1,8 mln rb., E. Strasburger, op. cit., s. 20. 
przyniosły w Rosji 231,1 mln rubli, w Królestwie - 18,7 mln rubli, tj. 8,1\% ogólnych wpływów budżetowych z tego źródła ${ }^{23}$.

W całym państwie rosyjskim przeciętne obciążenie podatkowe na mieszkańca, w rubryce podatków bezpośrednich, przewyższało nieco 90 kopiejek, w Królestwie Polskim dochodziło do 2 rubli (w pięcioleciu 1900-1905). Ciężar podatków bezpośrednich w Królestwie był zatem dwa razy większy niż w Cesarstwie ${ }^{24}$.

Administracja dziesięciu guberni Królestwa opłacała się skarbowi imperium w zupełności. W 1899 roku jeden mieszkaniec Królestwa wnosił do budżetu państwa 14 rubli 26 kopiejek. Jednocześnie za każdego rubla państwowych wydatków na lokalne potrzeby ludności wydawano 30 kopiejek. Natomiast aż $40 \%$ ogólnej sumy rozchodów w Królestwie szło na cele wojskowe ${ }^{25}$. Również w latach następnych potrzeby ludności nie były przez rząd carski dostatecznie uwzględniane, mimo że wydatki państwowe w Królestwie stale wzrastały. W okresie 1905-1911 wydatki wzrosły z 106699000 rubli do 124441000 rubli. Przyrost ten wynosił zatem $17 \%$, gdy dla całego państwa stanowił blisko $33 \%{ }^{26}$.

Wydatki skarbu w Królestwie wyniosły 203,6 mln rubli, czyli 19 rubli na jednego mieszkańca (w 1913 roku). Ogólna suma wydatków rządowych w Królestwie wyniosła $6,1 \%$ wydatków całego państwa. Największe były wydatki resortu skarbu, sprawiedliwości, spraw wewnętrznych, wojny i wydatki na zarząd długu państwowego. Nakłady na Ministerstwa Wojny, Spraw Wewnętrznych, Sprawiedliwości zawsze były w Królestwie znaczące i często wyższe niż w Rosji. Wydatki te służyły oczywiście interesom państwa, a nie miejscowej ludności ${ }^{27}$.

Charakterystyczne dla gospodarki rosyjskiej w Królestwie Polskim były wydatki na oświatę. Wynosiły one w 1913 roku 5 mln rubli, tj. zaledwie 3,7\% odnośnych wydatków w Rosji. Wydatki na rolnictwo - 2 mln rubli - stanowiły tylko 1,5\% odnośnych wydatków państwa, wydatki resortu handlu i przemysłu - 0,7 mln rubli, tj. 1,3\%. Zatem takie działy, jak: rolnictwo, handel, przemysł, czyli podstawowe dziedziny gospodarki, oraz oświata, były pod względem finansowym zaniedbane. Wydatki ponoszone przez rząd na rolnictwo, oświatę oraz komunikację ilustruje tabela.

${ }^{23}$ Ibid., s. 12.

${ }^{24}$ W. Żukowski, op. cit., s. 16.

${ }^{25}$ S. Dziewulski, op. cit., s. 119.

${ }^{26}$ Rocznik statystyczny..., s. 218.

${ }^{27}$ E. Strasburger, op. cit, s. 5-6. 
Tabela 4. Wydatki na rolnictwo, oświatę i komunikację w latach 1898-1913 (na 1 mieszkańca w rublach i kopiejkach)

\begin{tabular}{|l|c|c|c|c|c|c|c|}
\hline \multirow{2}{*}{} & \multicolumn{2}{|c|}{$\begin{array}{c}\text { Gubernia } \\
\text { petersburska }\end{array}$} & \multicolumn{2}{c|}{$\begin{array}{c}\text { Gubernia } \\
\text { moskiewska }\end{array}$} & \multicolumn{3}{c|}{ Królestwo Polskie } \\
\cline { 2 - 8 } & 1898 & 1907 & 1898 & 1907 & 1898 & 1907 & 1913 \\
\hline Rolnictwo & 2,74 & 2,07 & 0,26 & 0,27 & 0,11 & 0,07 & 0,14 \\
\hline Oświata & 2,06 & 0,99 & 1,09 & 1,07 & 0,25 & 0,26 & 0,38 \\
\hline Komunikacja & 32,90 & 23,30 & 10,19 & 18,91 & 1,26 & 2,01 & 3,80 \\
\hline
\end{tabular}

Źródło: E. Strasburger, op. cit, s. 6.

Odnośne wydatki w Królestwie były znacznie niższe niż w guberniach petersburskiej i moskiewskiej. W okresie 1898-1913 podniosły się w dość znacznym stopniu tylko wydatki na komunikację, a to w związku z budową nowych linii kolejowych ${ }^{28}$. Nakłady na koleje powiększyły się trzykrotnie, natomiast wydatki na rolnictwo i oświatę nadal pozostały na bardzo niskim poziomie. Szczególnie niskie były środki przeznaczane na szkolnictwo. Wynosiły one w 1907 roku w guberniach petersburskiej i moskiewskiej 1 rubla na mieszkańca, w Królestwie tylko 26 kopiejek (w 1913 roku - 38 kopiejek). Zatem z powyższego zestawienia można wyprowadzić ogólny wniosek, że potrzeby ludności polskiej nie były w sposób dostateczny zaspokajane przez rząd carski.

Królestwo Polskie było dla skarbu rosyjskiego obszarem wysoce dochodowym, dość znacznie obciążonym podatkami bezpośrednimi. Natomiast w zakresie wydatków nie przewyższało innych dzielnic, a nawet było pod tym względem upośledzone. Według wyliczeń W. Grabskiego w 1907 roku nadwyżka dochodów nad wydatkami w Królestwie wynosiła ponad 38 mln rubli. Królestwo należało więc do obszarów najbardziej produktywnych, wraz z takimi terenami, jak: gubernie centralno-czarnoziemne: połtawska, charkowska, woroneska, czernihowska; gubernia moskiewska; gubernie południowe: bessarabska, chersońska, taurydzka, jekaterynosławska, ziemia dońska. W dalszej kolejności pod względem dochodowości stały gubernie zachodnie: kowieńska, wileńska, grodzieńska, witebska, mohylewska, mińska; gubernie centralno-przemysłowe: twerska, włodzimierska, jarosławska, smoleńska, kałuska; gubernie nadbałtyckie i gubernia petersburska. Natomiast wydatki przewyższały dochody w guberniach małorosyjskich, wschodnich oraz pólnocno-zachodnich. Spośród guberni pozaeuropejskich znacznych dopłat wymagały Kaukaz i Syberia ${ }^{29}$.

${ }^{28}$ W 1912 roku upaństwowiono Kolej Warszawsko-Wiedeńską, ibid., s. 7.

${ }^{29}$ Nadwyżka dochodów nad wydatkami wynosiła w guberni moskiewskiej ponad $55 \mathrm{mln}$ rb., w guberniach południowych - również ponad $55 \mathrm{mln}$ rb., w guberniach centralno-czarno- 
W rezultacie gubernie centralno-czarnoziemne, południowe oraz Królestwo Polskie były rejonami najbardziej aktywnymi dla skarbu. Okręgi te, wraz z gubernią moskiewską, guberniami południowo-zachodnimi i centralno--przemysłowymi, dostarczały nadwyżek dochodów, dzięki którym rząd pokrywał kasowy deficyt rejonów południowo-zachodnich, wschodnich, Syberii i Kaukazu. Dodatkowo dzięki tym nadwyżkom rząd dysponował środkami na wydatki nadzwyczajne, które dotyczyły głównie takich rejonów, jak: Syberia, Kaukaz, Turkiestan, a także gubernie wschodnie i centralne. Obszary zachodnie imperium tylko w bardzo niewielkim stopniu uczestniczyły w wydatkach nadzwyczajnych. Skarb rosyjski nie dysponował specjalnymi środkami, które mógłby przeznaczyć na przekształcenie wschodu Europy, Kaukazu, północno-wschodniej Azji w rejony bardziej „cywilizowane”. Aby więc zrealizować na tych terenach jakieś projekty, rząd carski wykorzystywał środki, których dostarczały centralna Rosja i Królestwo Polskie ${ }^{30}$.

Podstawą finansową Rosji były podatki pośrednie, co w rezultacie obciążało szerokie masy ludności. Monopol wódczany był z kolei podstawą rosyjskich podatków państwowych i najważniejszą podporą rosyjskiej gospodarki finansowej. Budżet rosyjski otrzymał w związku z tym nazwę „budżetu pijanego" ${ }^{31}$. Olbrzymie dochody z monopolu ilustrowały w pewnym stopniu rosyjskie stosunki gospodarcze, potrzeby i obyczaje ludności. Odsłaniały także wielkie braki rosyjskiej gospodarki państwowej.

Ludność włościańska pod względem podatkowym była bardzo obciążona. Dotyczyło to podatków bezpośrednich, zwłaszcza jednak pośrednich, którymi obłożone były towary ogólnie konsumowane. Spośród ceł poważną rolę odgrywał dochód $\mathrm{z}$ herbaty, artykułu spożywanego przez szerokie kręgi ludności. Ludność włościańska była właściwie pod każdym względem nadmiernie obciążona, zarówno w stosunku do swoich dochodów oraz zdolności podatkowej, jak i w porównaniu z opodatkowaniem innych grup ludności. Zwłaszcza zdolność podatkowa ludności miejskiej była w Rosji słabo wykorzystana. Pozostawało to oczywiście w związku z agrarnym charakterem gospodarki rosyjskiej.

Co się tyczy udziału Królestwa Polskiego w rosyjskich finansach, to wykazywało ono stale czynny bilans finansowy, a dochody, które Rosja osiągała

ziemnych nawet ponad $61 \mathrm{mln}$ rb. Natomiast na Kaukazie niedobory finansowe wynosiły ponad $46 \mathrm{mln}$ rb., na Syberii - ponad $52 \mathrm{mln}$ rb., W. Grabski, op. cit., s. 31-32.

${ }^{30}$ Ibid., s. 35.

${ }^{31}$ E. Strasburger, op. cit., s. 23. 
z guberni polskich, przewyższały wydatki ${ }^{32}$. Bilans skarbowy Rosji za rok 1913 został przedstawiony w tabeli.

Tabela 5. Bilans skarbowy Rosji za rok 1913 (w mln rubli)

\begin{tabular}{|c|c|c|c|c|c|c|c|c|}
\hline & 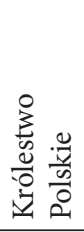 & 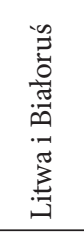 & $\stackrel{\text { 必 }}{\approx}$ & 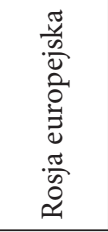 & 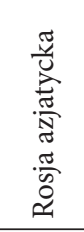 & 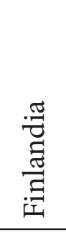 & 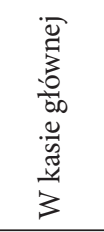 & $\begin{array}{l}\text { हี } \\
\text { : } \\
0 \\
0\end{array}$ \\
\hline Dochody zwyczajne & 295,5 & 100,6 & 210,8 & 1540,1 & 279,5 & 6,2 & 1029,8 & 3417,3 \\
\hline $\begin{array}{l}\text { Dochody } \\
\text { nadzwyczajne }\end{array}$ & - & - & - & 1,1 & 0,1 & - & 12,5 & 13,8 \\
\hline Ogółem & 295,5 & 100,6 & 210,8 & 1541,2 & 279,6 & 6,2 & 1042,3 & 3431,1 \\
\hline Wydatki zwyczaje & 203,6 & 140,3 & 160,3 & 1258,5 & 428,6 & 18,5 & 870,0 & 3040,4 \\
\hline $\begin{array}{l}\text { Wydatki } \\
\text { nadzwyczajne }\end{array}$ & - & 14,1 & 3,9 & 105,0 & 97,1 & 0,4 & 74,4 & 301,1 \\
\hline Ogółem & 203,6 & 154,4 & 164,2 & 1363,5 & 525,7 & 18,9 & 944,4 & 3341,5 \\
\hline $\begin{array}{l}\text { Nadwyżka } \\
\text { dochodów }\end{array}$ & 91,9 & - & 46,6 & 177,7 & - & - & 97,9 & 89,6 \\
\hline $\begin{array}{l}\text { Nadwyżka } \\
\text { wydatków }\end{array}$ & - & 33,8 & - & - & 246,0 & 12,7 & - & - \\
\hline
\end{tabular}

Źródło: E. Strasburger, op. cit., s. 25.

${ }^{32}$ W początkach XX stulecia kwestia udziału Królestwa w finansach Rosji była przedmiotem żywego zainteresowania. Na ten temat powstała obszerna literatura, także rosyjska. Większość ekonomistów rosyjskich wypowiadających się w tej kwestii, m.in. Jasnopolski, Polenow, Szwanebech, Saburow, starało się dowieść, że wydatki łożone na Królestwo nadmiernie obciążają skarb rosyjski i że jest ono uprzywilejowaną dzielnicą Rosji, ze szkodą dla innych prowincji. Z pisarzy polskich przytaczani niejednokrotnie W. Żukowski i W. Grabski podjęli się zadania udowodnienia, że w rzeczywistości jest inaczej, ibid., s. 25. 

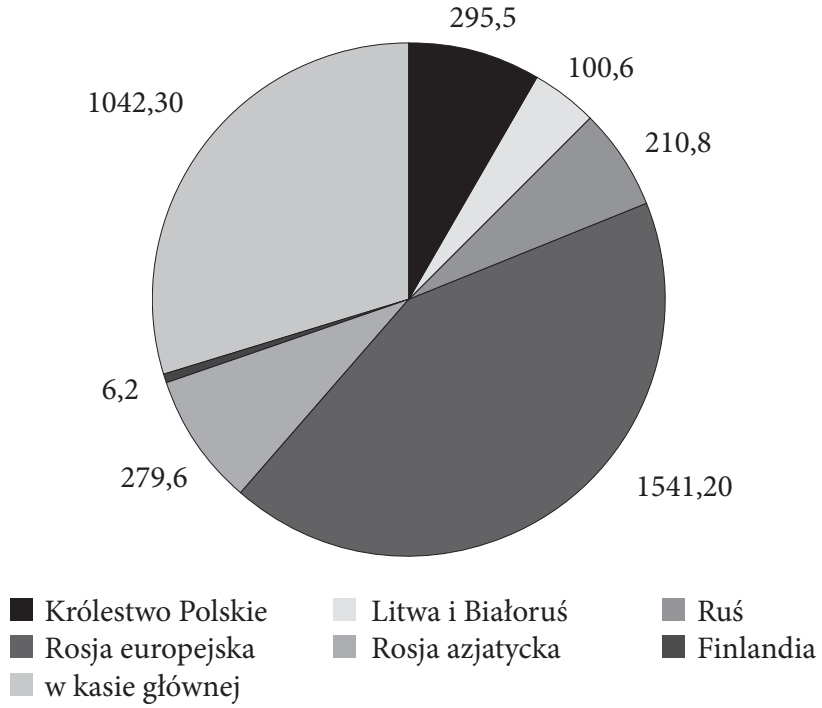

Wykres 1. Dochody budżetowe Rosji w 1913 roku (w mld rubli)

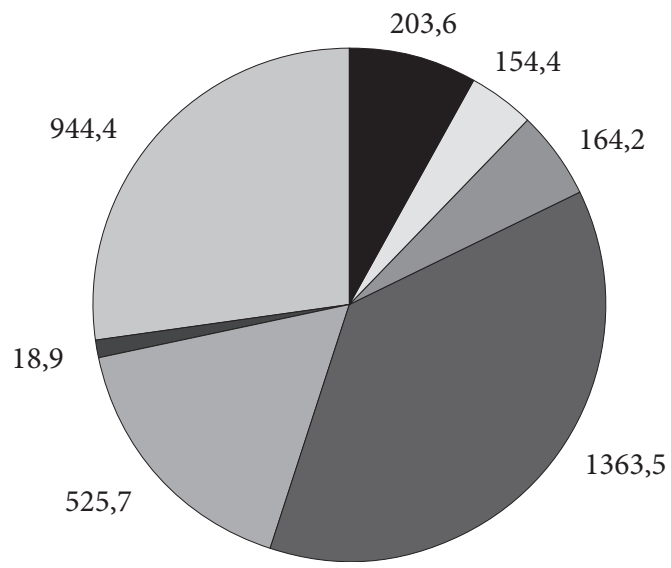
Królestwo Polskie
Rosja azjatycka
Litwa i Białoruś
- Finlandia
Rosja europejska
w kasie głównej

Wykres 2. Wydatki budżetowe w 1913 roku (w mld rubli)

Bilans Królestwa Polskiego w dochodach i wydatkach Rosji w 1913 roku wyrażał się nadwyżką 91,1 mln rubli. Zasadnicza teza o produktywności Króle- 
stwa dla finansów Rosji utrzymywała się w roku 1913, podobnie jak i w latach poprzednich.

Dla porównania - w 1913 roku krajem wybitnie czynnym pod względem finansowym była Ruś - Ukraina. Dała ona nadwyżkę 46,6 mln rubli. Głównym źródłem dochodu skarbowego na Rusi była akcyza od cukru, która stanowiła niemal połowę wszystkich dochodów rządowych w tym kraju. Cukrownictwo było bowiem podstawą miejscowej gospodarki.

Krajem pod względem finansowym wybitnie biernym była Finlandia, gdzie przy $6 \mathrm{mln}$ rubli dochodu wydatki rządowe stanowily $19 \mathrm{mln}$ rubli, zatem dla Rosji powstał deficyt około $13 \mathrm{mln}$ rubli. Bierny bilans skarbowy Finlandii związany był ze słabym rozwojem gospodarczym kraju, głównie wskutek niepomyślnych warunków klimatycznych. Ujemny bilans finansowy wykazywały także Litwa i Białoruś, gdzie przy $100 \mathrm{mln}$ rubli dochodu wydatki sięgały $154 \mathrm{mln}$ rubli.

Królestwo Polskie należało do nielicznych prowincji Rosji wykazujących czynny bilans skarbowy. O dochodach i wydatkach państwowych rozstrzygał stan gospodarczy kraju. Królestwo Polskie, kraj przemysłowy oraz względnie bogaty w stosunku do innych dzielnic Rosji, dawał państwu wyższe dochody w porównaniu do liczby ludności, mianowicie 8,5\% ogólnych dochodów. Niektóre pozycje były w Królestwie wyższe od współczynnika ludnościowego. Znaczny dochód z kolei i poczty związany był z ożywionym ruchem osobowym oraz towarowym, a także korespondencją i wysyłaniem przesyłek pocztowych na terytorium Królestwa ${ }^{33}$.

Podatki bezpośrednie dawały na obszarze Królestwa 12\% wszystkich wpływów w 1913 roku, podczas gdy w Rosji tylko 8\%. Mieszkaniec Królestwa płacił przeciętnie podatków bezpośrednich - 2 ruble 70 kopiejek (w 1913 roku), mieszkaniec Rosji mniej więcej połowę tego - 1 rubla 40 kopiejek. Wynikało to z lepszej kultury rolnej i wyższego opodatkowania ziemi oraz nieruchomości miejskich w Królestwie ${ }^{34}$.

Wysokie dochody płynęły także z Królestwa z niektórych towarów, z których płaciło się akcyzę, zwłaszcza tytoniu i cukru. Wreszcie stempel i podatek spadkowy przynosiły znaczne wpływy, z uwagi na wyższy stopień rozwoju gospodarczego i ze względu na większą liczbę aktów notarialnych, co związane było z przemysłowo-miejskim charakterem kraju.

Reasumując, pod względem wymienionych wyżej różnych kategorii dochodów Królestwo Polskie było obszarem wysoce produktywnym dla skarbu

\footnotetext{
${ }^{33}$ Ibid., s. 27.

${ }^{34}$ Ibidem.
} 
rosyjskiego, głównie dzięki stosunkowo wysokiemu rozwojowi gospodarczemu $\mathrm{w}$ porównaniu $\mathrm{z}$ innymi dzielnicami państwa.

Polityka finansowa imperium carskiego była skierowana na osiąganie coraz wyższych wpływów budżetowych. Wzrostowi dochodów państwowych sprzyjał szybki rozwój ekonomiczny kraju. Rosły one stale i systematycznie. Dotyczyło to zwłaszcza wpływów z podatków obciążających tak dynamicznie rozwijające się dziedziny gospodarki, jak przemysł czy budownictwo miejskie. Rosła dochodowość podatków pośrednich, głównie dzięki wzrostowi spożycia artykułów obłożonych akcyzą. Proces ten dotyczył także Królestwa Polskiego, które w tym czasie wyrosło na jedną z najszybciej rozwijających się pod względem ekonomicznym prowincji imperium. Stąd też skarb rosyjski czerpał niemałe dochody.

\section{ZUSAMMENFASSUNG}

Der Artikel ist eine Probe der Vorstellung von der Frage der Einkommensteilnahme vom Königreich Polen am Haushalt des russischen Staats um die Wende des XIX. zum XX. Jahrhundert. Dieses Problem erregte Interesse der bedeutendsten polnischen Wirtschaftswissenschaftler, vor allem Anfang des XX. Jahrhunderts. In Anlehnung an die in der Literatur dieser Periode enthaltenen Daten kann man zum Schluss kommen, dass das Königreich Polen eine sehr gewinnbringende Provintz für den russischen Fiskus war, vor allem infolge der ziemlich hohen und dynamischen wirtschaftlichen Entwicklung. Zugleich war es ein Gebiet, wo die Steuerbelastungen, insbesondere wenn es um die direkten Steuern geht, erheblich höher als die in anderen Provinzen des Zarenimperiums waren. 